\title{
Presence and persistence of Pseudomonas sp. during Caspian Sea-style spontaneous milk fermentation highlights the importance of safety and regulatory concerns for traditional and ethnic foods
}

\author{
Bruna Leal MASKEa , Gilberto Vinícius de Melo PEREIRA a* (D), Dão Pedro de CARVALHO NETOa, \\ Juliano de Dea LINDNER ${ }^{\mathrm{b}}$, Luiz Alberto Júnior LETTII ${ }^{\mathrm{a}}$, Maria Giovana PAGNONCELLI ${ }^{\mathrm{c}}$, Carlos Ricardo SOCCOL ${ }^{\mathrm{a}}$
}

\begin{abstract}
The aim of this study was to evaluate the performance of Caspian Sea-style spontaneous milk fermentation to improve the quality of pasteurized milk containing high levels of Pseudomonas contamination, with a focus on microbiological safety and stability of the final product. Bacterial diversity of pasteurized milk, fermentation process, and after 60 days of storage was analyzed by Illumina-based sequencing, and presence of viable taxa was confirmed by culturing on selective media. Low quality pasteurized milk harbored mainly Gram-negative bacteria, markedly dominated by Pseudomonas. Following fermentation, lactic acid bacteria rapidly became dominant with maximum population of $10.15 \log \mathrm{CFU} / \mathrm{mL}$ at $18 \mathrm{~h}$, represented mainly by Lactococcus. However, sequences related to Pseudomonas, and to a lesser extent for enterobacteria, remained constant throughout the fermentation process. The cultured-dependent approach confirmed the presence of viable Pseudomonas, with a final population of $5.60 \log \mathrm{CFU} / \mathrm{mL}$. Biochemical transformations were further analyzed, indicating lactic acid as the main end-metabolite produced (maximum concentration of $5.93 \mathrm{~g} / \mathrm{L}$ at $24 \mathrm{~h}$ ). In addition, the increase of 2-nonanone can be correlated as a volatile biomarker of $P$. aeruginos $a$ and related species. Altogether, the results demonstrated that natural milk fermentation may often not inhibit the development of pathogens and food spoilage microorganisms.
\end{abstract}

Keywords: fermented milk; food-borne microorganisms; lactic acid fermentation; food safety; probiotic.

Practical Application: Food safety authorities in Brazil need to conduct rigorous surveillance of fermented milk products.

\section{Introduction}

The emergence of dairying was a critical step in early agriculture, with considerable importance in the human diet (Panesar, 2011). As a rich nutritional source for microbial growth, prehistoric farmers used lactic acid fermentation to prolong the shelf life of milk (Carrer et al., 2016). The finding of abundant milk residues in pottery vessels from seventh- millennium sites from north-western Anatolia provided the earliest evidence of milk processing (Salque et al., 2013). Until now, fermented dairy products have been a vital component in the daily diet of ethnic groups all around the world, and play an important nutritional role in modern life (Granato et al., 2010).

The popularity and the availability of fermented dairy products (e.g., kefir, koumiss, curd, lassi, laben, and Suero costeño) have been increased throughout the world due to their functional properties and prolonged shelf-life, given by the dynamics of the microbial community living there (Grandos Conde et al., 2013; Panesar, 2011; Singh \& Shah, 2017). The fermentation is based on the indigenous microbiota present in the raw material or using part of a successful fermentation as back-slopping in order to ensure the dominance of the original microbiota (Capozzi et al., 2012; Pereira et al., 2020; Capozzi et al., 2020). Caspian Sea-style spontaneously fermented milk is widespread as an traditional product. It is usually produced by natural fermentation (12-24 h) of raw cow's milk at ambient temperature (approximately $25^{\circ} \mathrm{C}$ ) (Kiryu et al., 2009). The finished product has a highly viscous consistency with a pleasant acid taste, due to the presence of Lactococcus lactis ssp. cremoris and, to a lesser extent, Leuconostoc sp., Gluconobacter sp., and Acetobacter orientalis (Ishida et al., 2005; Uchida et al., 2009). In Brazil, a similar fermented milk is produced by different families (private households) that believe the "mother inoculum" is originated from Caucasus region, so-called Caspian Sea-style fermented milk. However, there are no studies of this traditional product circulated in Brazil.

Although natural fermented milk products harbored various beneficial microorganisms, they are susceptible to contamination due to the conduct of fermentation in open systems and poor microbiological quality of the raw material (Capozzi et al., 2017). Pseudomonas spp. is a relevant contaminant for fermented milk products (Del Olmo et al., 2018; Reichler et al., 2018; Scatamburlo et al., 2015). Due to their high metabolic versatility, Pseudomonas are able to survive in different environments, such as food, soil, water, and air (Scatamburlo et al., 2015). In raw milk, Pseudomonas are the dominant group due to 
their proteolytic activity (Ercolini et al., 2009). In addition, Pseudomonas have also been found in pasteurized milks due to post-pasteurization contamination or processing environment (Gennari \& Dragotto, 1992; Reichler et al., 2018). Reichler et al. (2018) identified the contaminating bacteria of pasteurized milk samples from 10 facilities across the northeastern United States. The study revealed that $76.5 \%$ of the spoiled samples were contaminated with Pseudomonas sp., and 8 out of 10 facilities showed repeat isolation one or more Pseudomonas strains, suggesting a difficulty on controlling this microorganism in the supplying industries. Thus, the use of low-quality milk can affect the bacterial ecosystem through fermentation processes and compromise both quality and health-assurance of finalized products (Leitner et al., 2008; Motato et al., 2017).

The emergence of high-throughput sequencing (HTS) technologies has revolutionized the way to investigate microbial diversity of traditional fermentations. These recent platforms have enabled the discovery of several uncultivable microorganisms, sub-dominant populations, and late-growing species, overlooked by culture-based approaches. In the field of food microbial ecology, different HTS platforms have been used for community analysis, including 454 pyrosequencing from Roche, SOLiD/Ion Torrent PGM from Life Sciences, and Genome Analyzer/HiSeq 2000/ MiSeq from Illumina (Dertli \& Çon, 2017; Humblot \& Guyot, 2009; Serafini et al., 2014). These platforms have been used to accurately detect, identify, and characterize foodborne pathogens without any culturing step (Jagadeesan et al., 2019; Leonard et al., 2015).

The aim of this study was to evaluate the performance of Caspian-style milk spontaneous fermentation using low quality milk as a raw material, with focus on microbiological safety and stability of the final product. Due to the high incidence and persistence of Pseudomonas found in this study, we applied culture-dependent methods to confirm the presence of viable taxa. In addition, biochemical transformation dynamics (sugar consumption and end-metabolite generation) were examined for better insight into microbial activity during the process.

\section{Materials and methods}

\subsection{Fermentation and sampling}

The sample of domestic fermented milk was obtained from a private household that traditionally produce Caspian Sea-style spontaneously fermented milk through back-slopping in Curitiba city, Paraná State, Brazil. $50 \mathrm{~mL}$ of the "mother" culture was inoculated into $450 \mathrm{~mL}$ pasteurized whole cow's milk and renewed daily in the same proportion $(10 \% \mathrm{vol} / \mathrm{vol})$ at $25^{\circ} \mathrm{C}$ for 7 days. This was performed for microbial stabilization before experimental fermentation.

$100 \mathrm{~mL}$ of resulting fermented milk ("mother" culture) was transferred in triplicate into 2-L Erlenmeyer flasks, containing $900 \mathrm{~mL}$ of industrially pasteurized milk of low microbiological quality, and incubated under static condition at $25^{\circ} \mathrm{C}$ for $24 \mathrm{~h}$. The low-quality milk, purchased at a local Curitiba market, was selected after quantification of Pseudomonas, a common contaminant in pasteurized milk, on Pseudomonas F agar (PFA; Thermo Fisher Oxoid). The milk samples that reached plate counts above $20,000 \mathrm{CFU} / \mathrm{mL}$ were selected for the fermentation assay (Alles et al., 2018).
Samples $(20 \mathrm{~mL})$ of fermenting milk in triplicate were collected at intervals of 6 hours $(0,6,12,18$, and $24 \mathrm{~h})$ to perform microbiological and metabolite target analysis. At each sampling point, the $\mathrm{pH}$ was measured using a digital $\mathrm{pH}$ meter (LUCA-210 model, Requipal, Curitiba, PR, Brazil). The resulting fermented product was stored at $4{ }^{\circ} \mathrm{C}$ for 60 days (storage stability) and submitted to both culture-dependent and-independent microbiological analyses.

\subsection{Total DNA extraction and high-throughput sequencing}

Samples of pasteurized milk, fermentation times, and storage stability were withdrawn to perform total genomic DNA extraction and metagenetic analysis. The extraction protocol was performed according Junqueira et al (2019), with slightly modifications. The cell pellets, obtained after centrifugation of each sample at $12,000 \times g$ for $1 \mathrm{~min}$, were resuspended in $500 \mu \mathrm{L}$ Tris-EDTA ( $\mathrm{pH} 8.0$ ), vortexed with $10 \mu \mathrm{L}$ of lysozyme solution at $20 \mathrm{mg} / \mathrm{mL}$ (Sigma Aldrich, San Louis, MO, USA), and incubated at $30^{\circ} \mathrm{C}$ for $60 \mathrm{~min}$. Then, $50 \mu \mathrm{L}$ of sodium dodecyl sulfate $(10 \% \mathrm{w} / \mathrm{v}$ in distilled, deionized water) and $10 \mu \mathrm{L}$ of proteinase $\mathrm{K}$ solution (20 mg/mL in deionized water; Sigma Aldrich) were added to the lysis solution, followed by incubation at $60^{\circ} \mathrm{C}$ during $60 \mathrm{~min} .150 \mu \mathrm{L}$ of phenol-chloroform (25:24; Sigma Aldrich) was added, homogenized by inversion, and centrifuged at 12,000 $\times g$ for $5 \mathrm{~min}$. The supernatant was collected, and the DNA was precipitated with $3 \times(v / v)$ absolute ethanol. Pellets were washed with $80 \%$ ethanol, dried, and resuspended in ultrapure water. Extracted DNA quality was checked on a $0.8 \%(\mathrm{w} / \mathrm{v})$ agarose gel and quantified with the Nanodrop 2000 spectrophotometer (Thermo Fisher Scientific, Waltham, MA, USA).

Twenty ng of the extracted DNA, containing complementary adaptors for Illumina platform, was amplified using degenerated primers for the hypervariable V4 region of $16 \mathrm{~S}(515 \mathrm{~F}$ and 806R) rRNA gene (Caporaso et al., 2012). Bar-coded amplicons were generated by PCR following conditions described by Junqueira et al., (2019). Samples were sequenced in the MiSeq platform using the $500 \mathrm{~V} 2 \mathrm{kit}$, following standard Illumina protocols. Resulting sequences in FASTQ files were deposited in the NCBI Sequence Read Archive (SRA) repository with accession BioProject ID PRJNA592162.

\subsection{Bioinformatic analyses}

After sequencing, chimeric sequences detection, removal of noises from pre-cluster, and taxonomic attribution were performed using standard parameters of QIIME software package, version 1.9.0. Applying the UCLUST method (Edgar, 2010), sequences presenting identity above $97 \%$ were considered the same operational taxonomic units (OTUs) according to the SILVA database (Quast et al., 2013).

\subsection{Microbial counts}

Aliquots of $1 \mathrm{~mL}$ of each sample (pasteurized milk, fermentation times, and storage stability) were vortexed with $9 \mathrm{~mL}$ of $0.1 \%$ saline-peptone water $\left(10^{-1}\right.$ solution $)$ and diluted serially. Total aerobic bacteria (TAB) was enumerated on Nutrient Agar medium (NA; Thermo Fisher Oxoid, Waltham, MA, USA), lactic acid bacteria (LAB) on De Man, Rogosa, and 
Sharpe Agar (MRS, Thermo Fisher Oxoid), and Pseudomonas on Pseudomonas F agar (PFA; Thermo Fisher Oxoid); all media containing $0.1 \%$ (w/v) nystatin (Sigma Aldrich, San Louis, MO, USA) for fungal growth inhibition. NA and MRS plates were incubated at $30^{\circ} \mathrm{C}$ for $24 \mathrm{~h}$, and PFA plates were incubated at $37^{\circ} \mathrm{C}$ for $48 \mathrm{~h}$. Subsequently, the numbers of cell-forming units (CFU) were recorded.

\subsection{Substrates and metabolites}

Lactose consumption and organic acids production were determined at intervals of 6 hours $(0,6,12,18$, and $24 \mathrm{~h})$ by high-performance liquid chromatography (HPLC) according to Junqueira et al. (2019), with slightly modifications. Aliquots of $2 \mathrm{~mL}$ were centrifuged at $6000 \times \mathrm{g}$ for $15 \mathrm{~min}$ and filtered through a $0.22 \mu \mathrm{m}$ pore size hydrophilic Polyethersulfone (PES) membrane (Millipore Corp., Burlington, MA, USA). $100 \mu \mathrm{L}$ of filtered samples were injected into the HPLC system, equipped with an Aminex HPX $87 \mathrm{H}$ column $(300 \times 7.8 \mathrm{~mm}$; Bio-Rad, Richmond, CA, USA), and a refractive index (RI) detector (HPG1362A; Hewlett-Packard Company, Palo Alto, CA, USA). The column was eluted in an isocratic mode with a mobile phase of $5 \mathrm{mM}$ $\mathrm{H}_{2} \mathrm{SO}_{4}$ at $60^{\circ} \mathrm{C}$, and a flow rate of $0.6 \mathrm{~mL} / \mathrm{min}$.

The extraction of volatile compounds was performed using a headspace (HS) vial coupled to a SPME fiber (CAR/PDMS df75 $\mu \mathrm{m}$ partially crosslinked, Supelco., Saint Louis, MO, USA). For each determination, $2 \mathrm{~mL}$ of sample was stored in a $20 \mathrm{~mL}$ HS vial, in triplicate. The SPME fiber was exposed for $30 \mathrm{~min}$ at $60^{\circ} \mathrm{C}$. The compounds were thermally desorbed into the GC injection system gas phase (GC-MS TQ Series 8040 and 2010 Plus GC-MS; Shimadzu, Tokyo, Japan) at $260^{\circ} \mathrm{C}$. The column oven temperature was maintained at $60^{\circ} \mathrm{C}$ for $10 \mathrm{~min}$, followed by two heating ramps of 4 and $10^{\circ} \mathrm{C} / \mathrm{min}$ until reaching the temperatures of 100 and $200{ }^{\circ} \mathrm{C}$, respectively. The compounds were separated on a column 95\% PDMS/5\% PHENYL (30 m $\times 0.25 \mathrm{~mm} \times 0.25 \mathrm{~mm}$ film thickness). The GC was equipped with an HP 5972 mass selective detector (Hewlett Packard, Palo Alto, CA, USA). The compounds were identified by comparison to the mass spectra from library databases (Nist'98 and Wiley7n). For quantification, standard solutions of ethanol were prepared in different concentration levels $(1,10,20,50$, 100 and $1000 \mu \mathrm{mol} \mathrm{L}^{-1}$ ) and used to construct a calibration curve. The volatile compound concentrations were expressed as $\mu \mathrm{mol} \mathrm{L}{ }^{-1}$ of headspace, as ethanol equivalent.

\subsection{Statistical analysis}

The data obtained of microbial count and target metabolites were analyzed by post-hoc comparison of means by Duncan's test. Statistical analyses were performed using the SAS program (Statistical Analysis System Cary, NC, USA). The level of significance was established in a two-sided $p$-value $<0.05$.

\section{Results and discussion}

\subsection{Microbiological analysis}

A total of 651,747 Illumina paired-end reads (average of 93,107 reads/sample) were obtained and clustered into 215
OTUs at $97 \%$ sequence similarity. Rarefaction curve analysis showed a trend to level-off at the genus level, indicating that the majority of bacterial communities were covered (Supplementary Material, Figure S1). Sequences were classified, using QIIME and SILVA database, to the lowest possible taxonomic rank (i.e., genus level), and the results are represented in Figure 1. Selected low-quality pasteurized milk harbored mainly Gram-negative bacteria, markedly dominated by Pseudomonas (83.74\%), and subpopulations of Acinetobacter, Enterobacteriaceae, Sphingomonas, Staphylococcus, and Comamonadaceae, while Lactococcus (3.40\%) was the only Gram-positive bacteria found. Viable cell count of pasteurized milk on Pseudomonas-specific culture medium was $6.40 \log \mathrm{CFU} / \mathrm{mL}$, while $\mathrm{LAB}$ and $\mathrm{TAB}$ were not detected (Figure 2A). The milk used in this study was within the shelf life and stored under conditions ideal. Thus, it is possible to assume that failures occurred during the pasteurization process (Elmoslemany et al., 2010; Vidal et al., 2017; Martin et al., 2018; Russo et al., 2020). Recalls of pasteurized milk contaminated with spoilage bacteria are relatively frequent (Kumaresan \& Villi, 2008; Quigley et al., 2013; Samet-Bali et al., 2013; Walsh et al., 2016).

Following fermentation, the number of LAB was always higher, showing the maximum value of $10.15 \log \mathrm{CFU} / \mathrm{mL}$ at $18 \mathrm{~h}$ (Figure 2A). Similarly, TAB increased through the fermentation process, reaching $9.60 \log \mathrm{CFU} / \mathrm{mL}$ at $18 \mathrm{~h}$. Illumina-based amplicon sequencing showed that LAB population was mainly represented by Lactococcus, reaching $66 \%$ among the common OTUs at $6 \mathrm{~h}$ (Figure 1). Previous studies, using culture-dependent approaches, reported the dominance of Lactococcus lactis ssp. cremoris in Caspian Sea yogurt circulated in Japan, accompanied by species of Leuconostoc, Lactobacillus, Gluconobacter and Acetobacter (Kiryu et al., 2009; Uchida et al., 2009). Lactococcus dominance genus was confirmed in this study using Illumina-based amplicon sequencing. Lactococcus species have also been found as part of LAB members of other naturally fermented dairy products (Pérez Elortondo et al., 1998; Ferchichi et al., 2001; Fortina et al., 2003; López-Díaz et al., 2000). This microbial group has several important implications for fermentative process, including (i) milk acidification and casein proteolysis; (ii) metabolism of amino acids and fatty acids for flavor development; and (iii) action against food-borne pathogens and spoilage bacteria (El-Ghaish et al., 2011; Matamoros et al., 2009).

In addition, a more complex bacterial diversity, uncovered by the previous traditional cultivation studies, was revealed. These includes Leuconostoc, Pediococcus, Streptococcus, Plesiomonas, Bacillus, Sphingomonas, Acinetobacter, Comamonadaceae, Ruminococcaceae, Serratia, Prevotella, Staphylococcus, Chryseobacterium, Hydrogenophaga, Methylobacterium (Figure 1), and other 143 minor bacterial groups with relative prevalence $\leq 0.1 \%$ (Table S1). These findings indicate the need for the use of next-generation sequencing technologies for an in-deep knowledge of the microbial ecology of natural milk fermentation. The discovery of these new taxa will promote the best opportunities to isolate novel microorganisms with functional proprieties and, ultimately, their use as improved starters.

Even though Pseudomonas load decreased by more than $99 \%$ after $24 \mathrm{~h}$ of fermentation (8.29 to $5.60 \log \mathrm{CFU} / \mathrm{mL}$; Figure 2A), the significant final population can compromise the quality of 


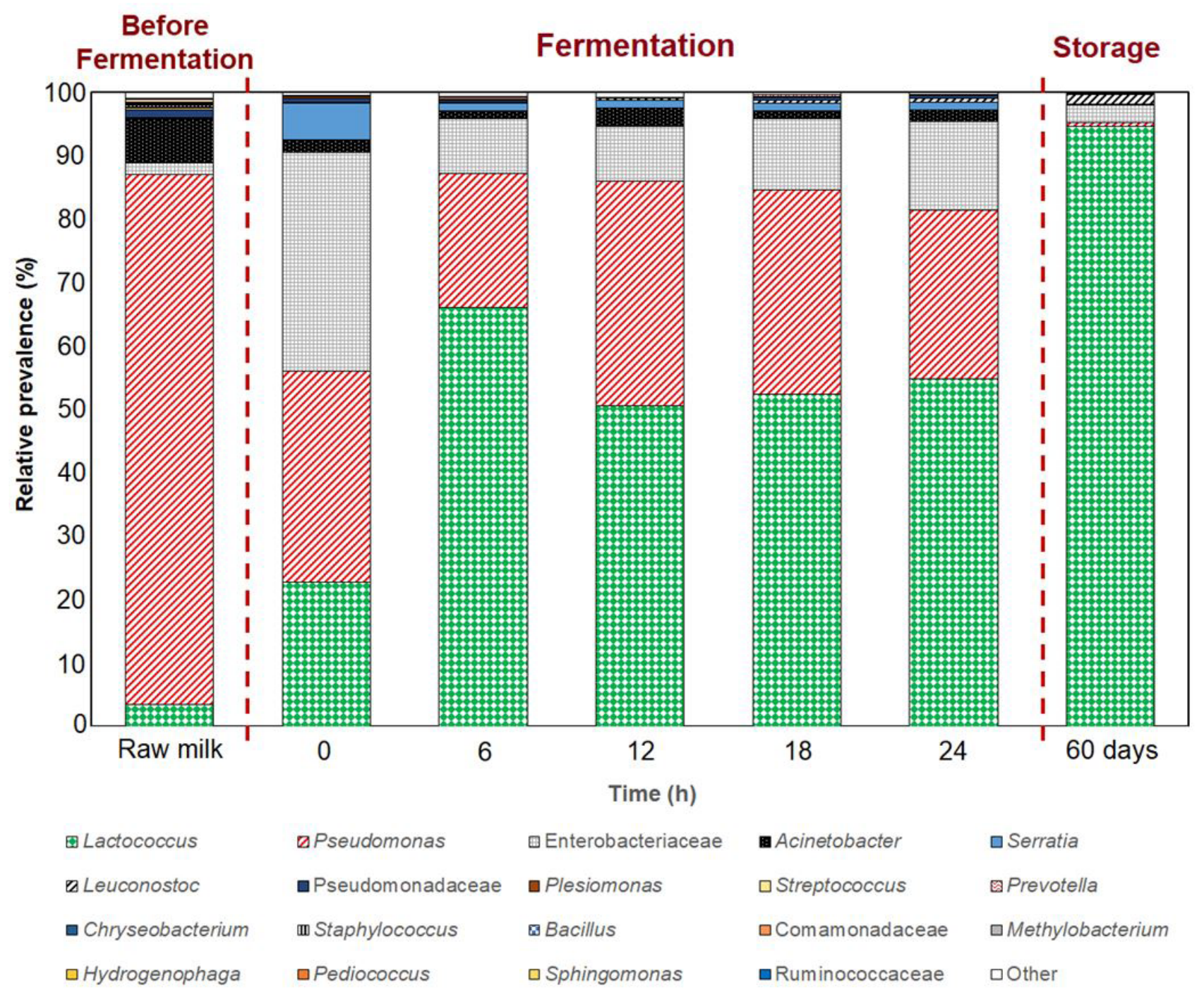

Figure 1. Relative bacterial abundance and dynamics during Caspian Sea-style spontaneous milk fermentation produced with low quality pasteurized milk. Low prevalence: bacterial groups with relative prevalence $\leq 0.1 \%$. The complete list of bacteria present at a low prevalence is shown in the supplemental material (Table S1).

the fermented product since Pseudomonas are known to produce various enzymes (e.g., lipases, proteases, and phospholipases) that lead to odor, flavor, and body defects (Chen et al., 2011). In addition, it may indicate potential health relevance when consumers believe they are ingesting only beneficial microorganisms. Although the incidence of Pseudomonas bacteremia from foods is very rare, some studies reported the presence of virulence in $P$. aeruginosa associated with fresh vegetables, water, and meat (Allydice-Francis \& Brown, 2012; Xu et al., 2019). Recent evidence suggests that virulence factors found in environmental isolates, such as pilin gene, multidrug efflux transport system, porin oprD gene, and haemolytic and proteolytic activities, show no difference with clinical P. aeruginosa (Allydice-Francis \& Brown, 2012). P. aeruginosa is considered an opportunistic pathogen, able to cause urinary tract infections, respiratory dermatitis, soft tissue infections, bacteremia, gastrointestinal infections, and a variety of systemic infections (Lucchetti-Miganeh et al., 2014; Sader et al., 2015; Castaldo et al., 2017). In this sense, great efforts are being explored to prevent contamination by Pseudomonas in dairy products (Meesilp \& Mesil, 2018; Nan et al., 2016; Picoli et al., 2017; Yasmin et al., 2017).

Sequences related to Enterobacteriaceae remained constant throughout the fermentation (Figure 1). The presence of Enterobacteriaceae indicates poor hygiene during the manufacturing process, and high numbers of enterobacteria have been linked to the accumulation of undesirable compounds with implications to flavor and texture defects in dairy products (Linares et al., 2012; Morales et al., 2003). Several studies showed the presence of enterobacteria in kefir grains (Dertli \& Çon, 2017; Walsh et al., 2016; Wang et al., 2006) and in cheese samples (Saxer et al., 2013). Dertli \& Çon (2017) showed that Enterobacter species can pass to the kefir grains from the milk, which should be assessed as they might create safety concerns. However, further studies using enterobacteria-selective culture media should be performed to confirm the presence of viable taxa through the 
Caspian Sea-style spontaneous milk fermentation. In addition, some Enterobacteriaceae genera could be not relevant as food-borne pathogens since many of them are plant commensal organisms (Jha et al., 2011).

There was a substantial discrepancy between viable cell count and Illumina-based amplicon sequencing; for example,
Pseudomonas spp. accounted for more than $20 \%$ of the 16 S rRNA gene sequences after $24 \mathrm{~h}$ (Figure 1), while culture-dependent analysis demonstrated that these organisms account for less than $1 \%$ of viable bacterial cells (Figure 2A). This discrepancy is frequently observed in DNA-dependent analyses after contaminants that were present in the raw material are killed while their DNA is still
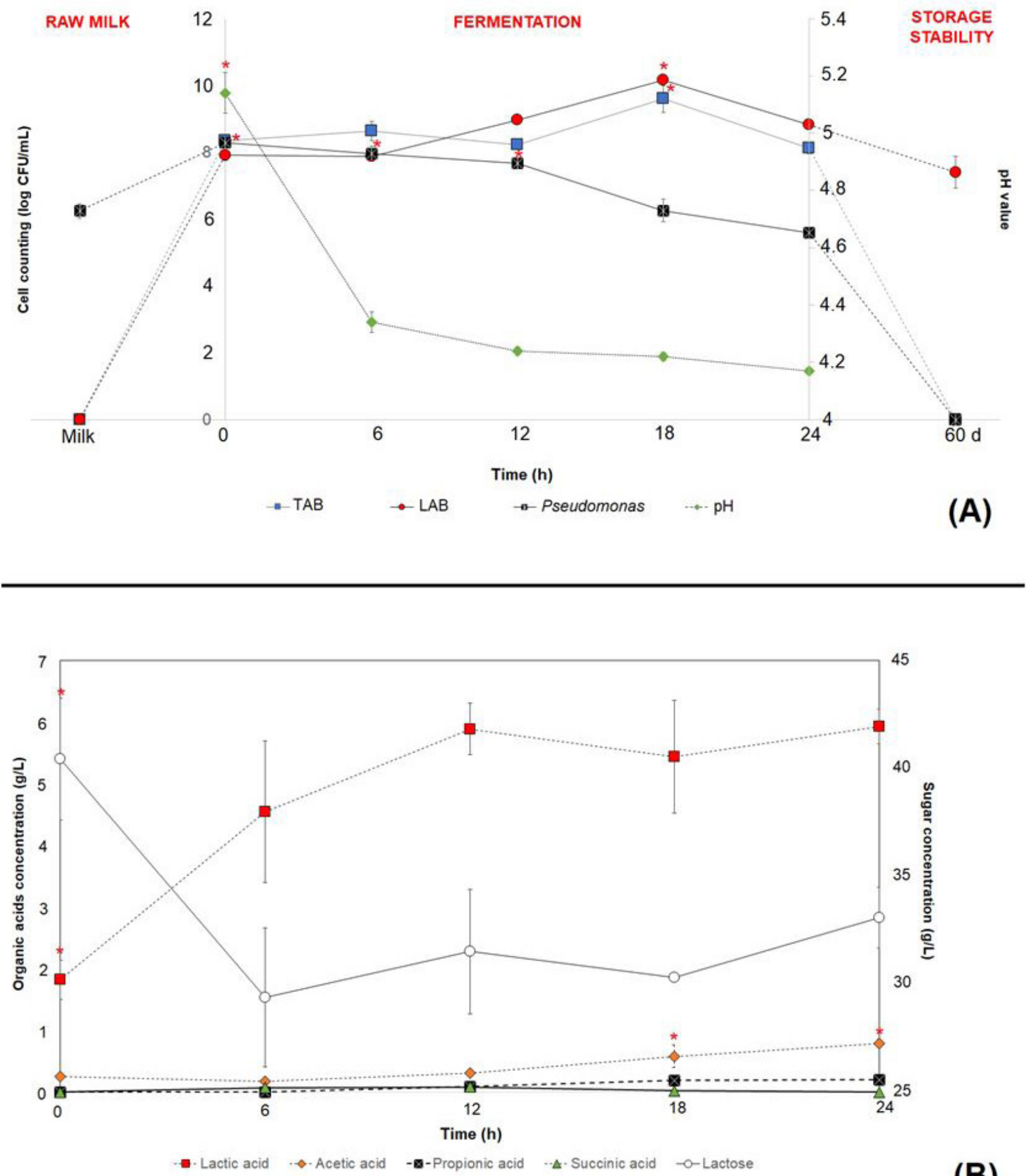

(B)

Figure 2. Viable cell count and biochemical changes during Caspian Sea-style spontaneous milk fermentation produced with low quality pasteurized milk. (A) Enumeration of lactic acid bacteria (LAB), total aerobic bacteria (TAB) and Pseudomonas, and pH monitoring; (B) Course of sugar consumption and organic acids production. Asterisk = significantly higher from one another in a two-sided $p$ value $<0.05$ according to Duncan's test. 
amplified (Mayo et al., 2014). This overestimation of $\beta$-diversity in culture-independent analysis is recurrently observed in several studies (Martínez et al., 2013; Ursell et al., 2012; Wen et al., 2017).

Interestingly, after the storage process at $4{ }^{\circ} \mathrm{C}$ for 60 days, LAB was present at $7.41 \log \mathrm{CFU} / \mathrm{mL}$ and Lactococcus represented $90 \%$ of total OTUs by sequencing (Figures 1 and 2). On the other hand, Pseudomonas was no longer detected by plating and represented less than $5 \%$ of total OTUs (Figures 1 and 2), indicating amplification of reminiscent dead cells (Mayo et al., 2014). The metabolites formed during the fermentation process promotes the survivability of LAB, maintaining their viability over storage time. It is widely known that refrigerated storage is a key point in LAB dominance, increasing shelf life of fermented beverages (Łopusiewicz et al., 2019). Even so, the sampled fermented product should still represent a health concern since Caspian Sea-style spontaneously fermented milk consumption is usually performed within a few days after refrigeration.

\subsection{Substrates and metabolites}

Changes in non-volatiles (lactose and organic acids) and volatile compounds (carboxylic acids, aldehydes, and ketones) were monitored during the course of the fermentation (Figure 2B and Table 1, respectively). The initial lactose content $(40.43 \mathrm{~g} / \mathrm{L})$ was rapidly reduced to $29.39 \mathrm{~g} / \mathrm{L}$ within $6 \mathrm{~h}$ and remained constant until the end of the process. Lactose is the main carbohydrate in milk, with an average concentration of around 5\% (w/v) (Barros et al., 2019). Fermentation reduces lactose in dairy products, helping to prevent symptoms in lactose-intolerant individuals (Savaiano, 2014). In the present study, the highest population of LAB was represented by the genus Lactococcus, which uses lactose by active transportation into the cytoplasm via phosphotransferase (PTS) system and hydrolyzing it into glucose and galactose (Mayo et al., 2010). Both monosaccharides enter glycolysis at the level of glucose-6P or metabolized via the Leloir pathway (Kandler, 1983; Mayo et al., 2010).

Lactic acid is the primary end-product observed, showing a continuous increase with maximum concentration of $5.93 \mathrm{~g} / \mathrm{L}$ at $24 \mathrm{~h}$. The accentuated production of lactic acid is in agreement with the strong dominance of LAB found in the present study (Figures 1 and 2), resulting in $\mathrm{pH}$ decrease from 5.10 to 4.10 at the end of fermentation. Lactic acid is the major fermentation product of various bacterial families related to dairy products. This compound is responsible for the raw milk acidification and partial casein coagulation, resulting in the formation of desirable sensory notes and rheological modifications. In addition, lactic acid is the main antimicrobial metabolite produced by $\mathrm{LAB}$, which is responsible for the inhibition of various pathogens and food-borne microorganisms (Chahad et al., 2012; Gálvez et al., 2010; Nakajima et al., 2003; Nakai \& Siebert, 2004). Specifically, Nakai \& Siebert (2004) showed that $P$. aeruginosa was extremely sensitive to lactic acid, having the lowest MIC (minimum inhibitory concentration) among six different bacteria analyzed. Other factors that also contribute to antagonist action of $\mathrm{LAB}$ include the production of hydrogen peroxide, bacteriocins, and antibiotic-like substances

Table 1. Concentration of volatile aroma compounds $\left(\right.$ Area ${ }^{\star} 10^{5}$ ) formed during fermentation of Caspian Sea-style spontaneously fermented milk circulated in Brazil.

\begin{tabular}{|c|c|c|c|c|c|c|}
\hline Compounds & Aroma and taste description & \multicolumn{5}{|c|}{ Milk fermentation (h) } \\
\hline \multicolumn{7}{|l|}{$G C$} \\
\hline Hexanoic acid & Sour, fatty, sweaty, cheesy & $53.89 \pm 1.86^{\mathrm{a}}$ & $34.19 \pm 3.70^{\mathrm{b}}$ & $55.29 \pm 12.27^{\mathrm{a}}$ & $65.81 \pm 2.95^{\mathrm{ac}}$ & $71.11 \pm 1.23^{\mathrm{c}}$ \\
\hline Heptanoic acid & Cheesy, waxy, fermented pineapple & $1.29 \pm 0.11^{\mathrm{ab}}$ & $0.69 \pm 0.19^{\mathrm{ab}}$ & $0.96 \pm 0.39^{\mathrm{ab}}$ & $1.59 \pm 0.16^{\mathrm{a}}$ & $1.58 \pm 0.29^{\mathrm{a}}$ \\
\hline Benzoic acid & Balsamic & ND & $2.06 \pm 0.34^{\mathrm{a}}$ & $14.81 \pm 3.15^{\mathrm{b}}$ & $20.31 \pm 3.23^{b}$ & $21.00 \pm 2.53^{\mathrm{b}}$ \\
\hline Octanoic acid & Fatty, oily, cheesy & $68.10 \pm 3.66^{\mathrm{a}}$ & $62.83 \pm 9.76^{\mathrm{a}}$ & $69.31 \pm 17.14^{\mathrm{a}}$ & $96.61 \pm 1.12^{\mathrm{b}}$ & $97.98 \pm 12.41^{\mathrm{b}}$ \\
\hline Nonanoic acid & Cheesy, dairy & $0.54 \pm 0.01^{\mathrm{a}}$ & $0.53 \pm 0.01^{\mathrm{a}}$ & $0.72 \pm 0.18^{\mathrm{a}}$ & $0.74 \pm 0.00^{\mathrm{a}}$ & $0.81 \pm 0.22^{\mathrm{a}}$ \\
\hline \multicolumn{7}{|l|}{ Aldehydes (3) } \\
\hline Benzaldehyde & Almond, fruity, powdery, nutty & ND & ND & $1.05 \pm 0.47$ & ND & ND \\
\hline \multicolumn{7}{|l|}{ Ketones (3) } \\
\hline 2-Heptanone & Cheesy, fruity, ketonic & ND & $0.36 \pm 0.01^{\mathrm{a}}$ & $0.86 \pm 0.61^{\mathrm{a}}$ & ND & $0.43 \pm 0.20^{\mathrm{a}}$ \\
\hline 2-Nonanone & Cheesy, fruity & ND & ND & $0.31 \pm 0.24^{\mathrm{a}}$ & $0.58 \pm 0.03^{\mathrm{a}}$ & $0.35 \pm 0.01^{\mathrm{a}}$ \\
\hline$\delta$-dodelactone & Sweet, creamy, coconut, milky, & ND & $0.20 \pm 0.09^{\mathrm{a}}$ & $0.42 \pm 0.04^{\mathrm{a}}$ & $0.21 \pm 0.09^{\mathrm{a}}$ & $0.47 \pm 0.05^{\mathrm{a}}$ \\
\hline
\end{tabular}

ND, not detected; GC, gas chromatography. Means of triplicate in each row bearing the same letters are not significantly different ( $\mathrm{p}>0.05$ ) from one another using Duncan's Test (mean \pm standard variation). 
(Arqués et al., 2015). Other minor organic acids produced during the fermentative process can be associated with the growth of sub-dominant bacteria reported by the $16 \mathrm{~S}$ rRNA gene high-throughput sequencing, including succinic acid produced by Leuconostoc or Acinetobacter, propionic acid from hexose metabolism of Enterobacter species, and acetic acid by both acetic acid bacteria and heterofermentative LAB (Andriani et al., 2019; Souza et al., 2019; Kang et al., 2012).

Volatiles compound metabolites were, for the first time, measured during Caspian-sea milk fermentation. Twelve volatile compounds were detected by GC/MS during fermentation, including six carboxylic acids, three aldehydes, and three ketones (Table 1). Amongst the carboxylic acids class, benzoic, hexanoic, and octanoic acids showed a significant increase through the fermentation. Hexanoic and octanoic acids are mainly related to Lactococcus metabolism of lipids and have been associated with cheesy aroma in fermented milk beverages (Azizan et al., 2012; Ziadi et al., 2008). In addition, benzoic acid was detected after $6 \mathrm{~h}$ and showed a steady increase, reaching a maximum peak at $24 \mathrm{~h}$. This organic acid is commonly produced by species of Lactococcus, Lactobacillus, and Streptococcus through the conversion of hippuric acid, a natural component of milk. Benzoic acid has an inhibitory effect against spoilage microorganisms, such as yeast, mold, Listeria innocua, Listeria ivanovii, P. aeruginosa, and Oenococcus oeni (Garmiene et al., 2010; Horníčková et al., 2014; Nakai \& Siebert, 2004).

Ketones were the second class of volatile aroma reported. Both 2-heptanone and $\delta$-dodelactone were produced after $6 \mathrm{~h}$ of fermentation, referring to LAB activity of unsaturated fatty acids hydrolysis (Azizan et al., 2012; Wanikawa et al., 2002). These volatile compounds are commonly reported in the literature for conferring a cheesy-like aroma in fermented milk beverages (Braun, 2019; Walsh et al., 2016). On the other hand, 2-nonanone was produced after $18 \mathrm{~h}$, time in which Pseudomonas count showed a significant increase (Figure 1). This molecule has been recurrently used as a volatile biomarker for rapid detection of Pseudomonas aeruginosa and related species in hospital environments (Savelev et al., 2011; Zechman \& Labows, 1985). In this sense, this volatile can also be used for monitoring of quality control in dairy production facilities. Finally, as a minority group, the aldehydes nonanal, decanal, and benzaldehyde were produced at specific fermentation times, being mainly associated with lipid oxidation by LAB (Gänzle et al., 2007).

\section{Conclusions}

The results of this study demonstrated that Caspian Sea-style spontaneous milk fermentation is not an efficient tool to overcome poor microbiological quality of the milk used as raw material. Although Caspian Sea-style fermented milk showed a high load of LAB and lactic acid content, the presence and persistence of Pseudomonas and enterobacteria through fermentation indicate a potential health risk in the final fermented product. Because of the increased focus on consumption of naturally fermented dairy products, this is a major health concern, since the spread of pathogenic organisms can be facilitated among unsuspecting individuals. The use of poor quality pasteurized milk is also recurrent in other natural milk fermentation (e.g., kefir, koumiss, curd, lassi, laben, and Suero costeño) and further studies should be expanded to cover the safety status of these traditional foods. In addition, for a better understanding of Pseudomonas control using natural milk fermentation, it is crucial to evaluate different Pseudomonas inoculum concentration and more time during storage. The establishment of programs emphasizing hygienic manufacturing procedures can have a major effect on improving the microbiological quality of traditional and ethnic foods circulated in Brazil.

\section{References}

Alles, A. A., Wiedmann, M., \& Martin, N. H. (2018). Rapid detection and characterization of postpasteurization contaminants in pasteurized fluid milk. Journal of Dairy Science, 101(9), 7746-7756. http://dx.doi. org/10.3168/jds.2017-14216. PMid:29908800.

Allydice-Francis, K., \& Brown, P. D. (2012). Diversity of antimicrobial resistance and virulence determinants in Pseudomonas aeruginosa associated with fresh vegetables. International Journal of Microbiology, 2012, 426241. http://dx.doi.org/10.1155/2012/426241. PMid:23213336.

Andriani, A., Nuryana, I., Rahmani, N., Hartati, S., Lisdiyanti, P., \& Yopi, (2019). The potency of cassava starch (var. kristal merah and var. revita) for bio-succinic acid production using indigenous lactic acid bacteria (Leuconostoc sp). IOP Conference Series: Earth and Environmental Science, 251, 012039. http://dx.doi.org/10.1088/17551315/251/1/012039.

Arqués, J. L., Rodríguez, E., Langa, S., Landete, J. M., \& Medina, M. (2015). Antimicrobial activity of lactic acid bacteria in dairy products and gut: effect on pathogens. BioMed Research International, 584183, 584183. http://dx.doi.org/10.1155/2015/584183. PMid:25861634.

Azizan, K. A., Baharum, S. N., \& Noor, N. M. (2012). Metabolic profiling of Lactococcus lactis under different culture conditions. Molecules, 17(7), 8022-8036. http://dx.doi.org/10.3390/molecules17078022. PMid:22759915.

Barros, R. F., Cutrim, C. S., da Costa, M. P., Conte, C. A., Jr., \& Cortez, M. A. S. (2019). Lactose hydrolysis and organic acids production in yogurt prepared with different on set temperatures of enzymatic action and fermentation. Ciência Animal Brasileira, 20, e43549. http://dx.doi.org/10.1590/1809-6891v20e-43549.

Braun, M. (2019). Flavoured milk product Patent No. US2019/0021351A1.

Caporaso, J. G., Lauber, C. L., Walters, W. A., Berg-Lyons, D., Huntley, J., Fierer, N., Owens, S. M., Betley, J., Fraser, L., Bauer, M., Gormley, N., Gilbert, J. A., Smith, G., \& Knight, R. (2012). Ultra-highthroughput microbial community analysis on the Illumina HiSeq and MiSeq platforms. The ISME Journal, 6(8), 1621-1624. http:// dx.doi.org/10.1038/ismej.2012.8. PMid:22402401.

Capozzi, V., Fragasso, M., \& Russo, P. (2020). Microbiological safety and the management of microbial resources in artisanal foods and beverages: the need for a transdisciplinary assessment to conciliate actual trends and risks avoidance. Microorganisms, 8(2), 1-9. http:// dx.doi.org/10.3390/microorganisms8020306. PMid:32098373.

Capozzi, V., Fragasso, M., Romaniello, R., Berbegal, C., Russo, P., \& Spano, G. (2017). Spontaneous food fermentations and potential risks for human health. Fermentation, 3(4), 1-19. http://dx.doi.org/10.3390/ fermentation3040049.

Capozzi, V., Russo, P., \& Spano, G. (2012). Microbial information regimen in EU geographical indications. World Patent Information, 34(3), 229-231. http://dx.doi.org/10.1016/j.wpi.2012.04.001. 
Carrer, F., Colonese, A. C., Lucquin, A., Guedes, E. P., Thompson, A., Walsh, K., Reitmaier, T., \& Craig, O. E. (2016). Chemical analysis of pottery demonstrates prehistoric origin for high-altitude alpine dairying. PLoS One, 11(4), e0151442. http://dx.doi.org/10.1371/ journal.pone.0151442. PMid:27100391.

Castaldo, N., Givone, F., Peghin, M., Righi, E., Sartor, A., \& Bassetti, M. (2017). Multidrug-resistant Pseudomonas aeruginosa skin and softtissue infection successfully treated with ceftolozane/tazobactam. Journal of Global Antimicrobial Resistance, 9, 100-102. http://dx.doi. org/10.1016/j.jgar.2017.02.012. PMid:28495526.

Chahad, O. B., El Bour, M., Calo-Mata, P., Boudabous, A., \& BarrosVelàzquez, J. (2012). Discovery of novel biopreservation agents with inhibitory effects on growth of food-borne pathogens and their application to seafood products. Research in Microbiology, 163(1), 44-54. http://dx.doi.org/10.1016/j.resmic.2011.08.005. PMid:22041547.

Chen, T. R., Wei, Q. K., \& Chen, Y. J. (2011). Pseudomonas spp. and Hafnia alvei growth in UHT milk at cold storage. Food Control, 22(5), 697-701. http://dx.doi.org/10.1016/j.foodcont.2010.10.004.

Del Olmo, A., Calzada, J., \& Nuñez, M. (2018). The blue discoloration of fresh cheeses: a worldwide defect associated to specific contamination by Pseudomonas fluorescens. Food Control, 86, 359-366. http://dx.doi. org/10.1016/j.foodcont.2017.12.001.

Dertli, E., \& Çon, A. H. (2017). Microbial diversity of traditional kefir grains and their role on kefir aroma. Lebensmittel-Wissenschaft + Technologie, 85, 151-157. http://dx.doi.org/10.1016/j.lwt.2017.07.017.

Edgar, R. C. (2010). Search and clustering orders of magnitude faster than BLAST. Bioinformatics, 26(19), 2460-2461. http://dx.doi. org/10.1093/bioinformatics/btq461. PMid:20709691.

El-Ghaish, S., Ahmadova, A., Hadji-Sfaxi, I., El Mecherfi, K. E., Bazukyan, I., Choiset, Y., Rabesona, H., Sitohy, M., Popov, Y. G., Kuliev, A. A., Mozzi, F., Chobert, J. M., \& Haertlé, T. (2011). Potential use of lactic acid bacteria for reduction of allergenicity and for longer conservation of fermented foods. Trends in Food Science \& Technology, 22(9), 509-516. http://dx.doi.org/10.1016/j.tifs.2011.05.003.

Elmoslemany, A. M., Keefe, G. P., Dohoo, I. R., Wichtel, J. J., Stryhn, H., \& Dingwell, R. T. (2010). The association between bulk tank milk analysis for raw milk quality and on-farm management practices. Preventive Veterinary Medicine, 95(1-2), 32-40. http://dx.doi. org/10.1016/j.prevetmed.2010.03.007. PMid:20381889.

Ercolini, D., Russo, F., Ferrocino, I., \& Villani, F. (2009). Molecular identification of mesophilic and psychrotrophic bacteria from raw cow's milk. Food Microbiology, 26(2), 228-231. http://dx.doi. org/10.1016/j.fm.2008.09.005. PMid:19171267.

Ferchichi, M., Frère, J., Mabrouk, K., \& Manai, M. (2001). Lactococcin MMFII, a novel class IIa bacteriocin produced by Lactococcus lactis MMFII, isolated from a Tunisian dairy product. FEMS Microbiology Letters, 205(1), 49-55. http://dx.doi.org/10.1111/j.1574-6968.2001. tb10924.x. PMid:11728715.

Fortina, M. G., Ricci, G., Acquati, A., Zeppa, G., Gandini, A., \& Manachini, P. L. (2003). Genetic characterization of some lactic acid bacteria occurring in an artisanal protected denomination origin (PDO) Italian cheese, the Toma piemontese. Food Microbiology, 20(4), 397-404. http://dx.doi.org/10.1016/S0740-0020(02)00149-1.

Gálvez, A., Abriouel, H., Benomar, N., \& Lucas, R. (2010). Microbial antagonists to food-borne pathogens and biocontrol. Current Opinion in Biotechnology, 21(2), 142-148. http://dx.doi.org/10.1016/j. copbio.2010.01.005. PMid:20149633.

Gänzle, M. G., Vermeulen, N., \& Vogel, R. F. (2007). Carbohydrate, peptide and lipid metabolism of lactic acid bacteria in sourdough. Food Microbiology, 24(2), 128-138. http://dx.doi.org/10.1016/j. fm.2006.07.006. PMid:17008155.
Garmiene, G., Salomskiene, J., Jasutiene, I., Macioniene, I., \& Miliauskiene, I. (2010). Production of benzoic acid by lactic acid bacteria from Lactobacillus, Lactococcus and Streptococcus genera in milk. Milk Science International, 65(3), 295-298.

Gennari, M., \& Dragotto, F. (1992). A study of the incidence of different fluorescent Pseudomonas species and biovars in the microflora of fresh and spoiled meat and fish, raw milk, cheese, soil and water. The Journal of Applied Bacteriology, 72(4), 281-288. http://dx.doi. org/10.1111/j.1365-2672.1992.tb01836.x. PMid:1517169.

Granato, D., Branco, G. F., Cruz, A. G., Faria, J., \& Shah, N. P. (2010). Probiotic dairy products as functional foods. Comprehensive Reviews in Food Science and Food Safety, 9(5), 455-470. http://dx.doi. org/10.1111/j.1541-4337.2010.00120.x.

Grandos Conde, C., Acevedo Correa, D., \& Torres, R. (2013). Calidad de la leche y del suero costeño de los municipios Turbaco, Arjona y Carmen de Bolívar - Colombia. Revista Lasallista de Investigacion, 9(2), 132-137.

Horníčková, Š., Dragounová, H., Hejtmánková, K., Michlová, T., \& Hejtmánková, A. (2014). Production of benzoic acid in fermented goat's and sheep's milk. Scientia Agriculturae Bohemica, 45(4), 247-253. http://dx.doi.org/10.1515/sab-2015-0005.

Humblot, C., \& Guyot, J. P. (2009). Pyrosequencing of tagged 16S rRNA gene amplicons for rapid deciphering of the microbiomes of fermented foods such as pearl millet slurries. Applied and Environmental Microbiology, 75(13), 4354-4361. http://dx.doi. org/10.1128/AEM.00451-09. PMid:19411407.

Ishida, T., Yokota, A., Umezawa, Y., Toda, T., \& Yamada, K. (2005). Identification and characterization of lactococcal and Acetobacter strains isolated from traditional Caucasusian fermented milk. Journal of Nutritional Science and Vitaminology, 51(3), 187-193. http://dx.doi.org/10.3177/jnsv.51.187. PMid:16161770.

Jagadeesan, B., Gerner-smidt, P., Allard, M. W., Winkler, A., Xiao, Y., Chaffron, S., Van Der Vossen, J., Tang, S., Mcclure, P., Kimura, B., Chai, L. C., Chapman, J., Gmbh, C. D., Global, M., Safety, F., Zone, E. D., Osaka, I., Lane, B., \& Kingdom, U. (2019). The use of next generation sequencing for improving food safety: translation into practice. Food Microbiology, 79, 96-115. http://dx.doi.org/10.1016/j. fm.2018.11.005. PMid:30621881.

Jha, C. K., Aeron, A., Patel, B. V., Maheshwari, D. K., \& Saraf, M. (2011). Bacteria in agrobiology: plant growth responses. In D. K. Maheshwari (Ed.), Bacteria in agrobiology: plant growth responses (pp. 159-182). Berlin: Springer-Verlag. http://dx.doi.org/10.1007/9783-642-20332-9_8

Junqueira, A. C. O., Pereira, G. V. M., Medina, J. D. C., Alvear, M. C. R., Rosero, R., Carvalho, D. P., No., Enríquez, H. G., \& Soccol, C. R. (2019). First description of bacterial and fungal communities in Colombian coffee beans fermentation analysed using Illumina-based amplicon sequencing. Scientific Reports, 9(1), 1-10. http://dx.doi. org/10.1038/s41598-019-45002-8. PMid:30626917.

Kandler, O. (1983). Carbohydrate metabolism in lactic acid bacteria. Antonie van Leeuwenhoek, 49(3), 209-224. http://dx.doi.org/10.1007/ BF00399499. PMid:6354079.

Kang, S. M., Khan, A. L., Hamayun, M., Shinwari, Z. K., Kim, Y. H., Joo, G. J., \& Lee, I. J. (2012). Acinetobacter calcoaceticus ameliorated plant growth and influenced gibberellins and functional biochemicals. Pakistan Journal of Botany, 44(1), 365-372.

Kiryu, T., Kiso, T., Nakano, H., Ooe, K., Kimura, T., \& Murakami, H. (2009). Involvement of Acetobacter orientalis in the production of lactobionic acid in Caucasian yogurt ("Caspian Sea yogurt") in Japan. Journal of Dairy Science, 92(1), 25-34. http://dx.doi.org/10.3168/ jds.2008-1081. PMid:19109260. 
Kumaresan, G., \& Villi, R. A. (2008). Incidence of Pseudomonas species in pasteurized milk. Tamilnadu Journal of Veterinary \& Animal Sciences, 4(2), 56-59.

Leitner, G., Silanikove, N., Jacobi, S., Weisblit, L., Bernstein, S., \& Merin, U. (2008). The influence of storage on the farm and in dairy silos on milk quality for cheese production. International Dairy Journal, 18(2), 109-113. http://dx.doi.org/10.1016/j.idairyj.2007.09.001.

Leonard, S. R., Mammel, M. K., Lacher, D. W., \& Elkins, C. A. (2015). Application of metagenomic sequencing to food safety: detection of shiga toxin-producing Escherichia coli on fresh bagged spinach. Applied and Environmental Microbiology, 81(23), 8183-8191. http:// dx.doi.org/10.1128/AEM.02601-15. PMid:26386062.

Linares, D. M., Del Río, B., Ladero, V., Martínez, N., Fernández, M., Martín, M. C., \& Álvarez, M. A. (2012). Factors influencing biogenic amines accumulation in dairy products. Frontiers in Microbiology, 3, 180. http://dx.doi.org/10.3389/fmicb.2012.00180. PMid:22783233.

López-Díaz, T. M., Alonso, C., Román, C., García-López, M. L., \& Moreno, B. (2000). Lactic acid bacteria isolated from a hand-made blue cheese. Food Microbiology, 17(1), 23-32. http://dx.doi.org/10.1006/ fmic.1999.0289.

Łopusiewicz, Ł., Drozłowska, E., Siedlecka, P., Mężyńska, M., Bartkowiak, A., Sienkiewicz, M., Zielińska-Bliźniewska, H., \& Kwiatkowski, P. (2019). Development, characterization, and bioactivity of non-dairy kefir-like fermented beverage based on flaxseed oil cake. Foods, 8(11), 544. http://dx.doi.org/10.3390/foods8110544. PMid:31684151.

Lucchetti-Miganeh, C., Redelberger, D., Chambonnier, G., Rechenmann, F., Elsen, S., Bordi, C., Jeannot, K., Attrée, I., Plésiat, P., \& Bentzmann, S. (2014). Pseudomonas aeruginosa genome evolution in patients and under the hospital environment. Pathogens, 3(2), 309-340. http:// dx.doi.org/10.3390/pathogens3020309. PMid:25437802.

Martin, N. H., Boor, K. J., \& Wiedmann, M. (2018). Symposium review: effect of post-pasteurization contamination on fluid milk quality. Journal of Dairy Science, 101(1), 861-870. http://dx.doi.org/10.3168/ jds.2017-13339. PMid:29103726.

Martínez, I., Muller, C. E., \& Walter, J. (2013). Long-term temporal analysis of the human fecal microbiota revealed a stable core of dominant bacterial species. PLoS One, 8(7), e69621. http://dx.doi. org/10.1371/journal.pone.0069621. PMid:23874976.

Matamoros, S., Pilet, M. F., Gigout, F., Prévost, H., \& Leroi, F. (2009). Selection and evaluation of seafood-borne psychrotrophic lactic acid bacteria as inhibitors of pathogenic and spoilage bacteria. Food Microbiology, 26(6), 638-644. http://dx.doi.org/10.1016/j. fm.2009.04.011. PMid:19527840.

Mayo, B., Aleksandrzak-Piekarczyk, T., Fernández, M., Kowalczyk, M., Álvarez-Martín, P., \& Bardowski, J. (2010). Updates in the metabolism of lactic acid bacteria. In F. Mozzi, R. R. Raya \& G. M. Vignolo (Eds.), Biotechnology of lactic acid bacteria: novel applications (pp. 3-33). Chichester: Wiley-Blackwell. http://dx.doi. org/10.1002/9780813820866.ch1

Mayo, B., Rachid, C., Alegria, A., Leite, A., Peixoto, R., \& Delgado, S. (2014). Impact of next generation sequencing techniques in food microbiology. Current Genomics, 15(4), 293-309. http://dx.doi.org /10.2174/1389202915666140616233211. PMid:25132799.

Meesilp, N., \& Mesil, N. (2018). Effect of microbial sanitizers for reducing biofilm formation of Staphylococcus aureus and Pseudomonas aeruginosa on stainless steel by cultivation with UHT milk. Food Science and Biotechnology, 28(1), 289-296. http://dx.doi.org/10.1007/ s10068-018-0448-4. PMid:30815321.

Morales, P., Fernández-García, E., \& Nuñez, M. (2003). Caseinolysis in cheese by Enterobacteriaceae strains of dairy origin. Letters in
Applied Microbiology, 37(5), 410-414. http://dx.doi.org/10.1046/j.1472765X.2003.01422.x. PMid:14633113.

Motato, K. E., Milani, C., Ventura, M., Valencia, F. E., Ruas-Madiedo, P., \& Delgado, S. (2017). Bacterial diversity of the Colombian fermented milk "Suero Costeño" assessed by culturing and high-throughput sequencing and DGGE analysis of $16 \mathrm{~S}$ rRNA gene amplicons. Food Microbiology, 68, 129-136. http://dx.doi.org/10.1016/j.fm.2017.07.011. PMid:28800820.

Nakai, S. A., \& Siebert, K. J. (2004). Organic acid inhibition models for Listeria innocua, Listeria ivanovii, Pseudomonas aeruginosa and Oenococcus oeni. Food Microbiology, 21(1), 67-72. http://dx.doi. org/10.1016/S0740-0020(03)00043-1.

Nakajima, H., Toba, T., Ito, A., Kudo, S., Sato, S., \& Sato, Y. (2003). The screening of hydrogen peroxide-producing lactic acid bacteria and their application to inactivating psychrotrophic food-borne pathogens. Current Microbiology, 47(3), 231-236. http://dx.doi. org/10.1007/s00284-002-3993-1. PMid:14570275.

Nan, L., Ren, G., Wang, D., \& Yang, K. (2016). Antibacterial performance of Cu-bearing stainless steel against Staphylococcus aureus and Pseudomonas aeruginosa in whole milk. Journal of Materials Science and Technology, 32(5), 445-451. http://dx.doi.org/10.1016/j. jmst.2016.01.002.

Panesar, P. S. (2011). Fermented dairy products: starter cultures and potential nutritional benefits. Food and Nutrition Sciences, 2(1), 47-51. http://dx.doi.org/10.4236/fns.2011.21006.

Pereira, G. V. M., Carvalho, D. P., No., Junqueira, A. C. D. O., Karp, S. G., Letti, L. A. J., Magalhães, A. I., Jr. \& Soccol, C. R. (2020). A review of selection criteria for starter culture development in the food fermentation industry. Food Reviews International, 36(2), 135167. http://dx.doi.org/10.1080/87559129.2019.1630636.

Pérez Elortondo, F. J., Aldámiz Echobarria, P., Albisu, M., \& Barcina, Y. (1998). Indigenous lactic acid bacteria in Idiazabal ewes' milk cheese. International Dairy Journal, 8(8), 725-732. http://dx.doi. org/10.1016/S0958-6946(98)00113-7.

Picoli, T., Peter, C. M., Zani, J. L., Waller, S. B., Lopes, M. G., Boesche, K. N., Vargas, G. D., Hübner, S. de O., \& Fischer, G. (2017). Melittin and its potential in the destruction and inhibition of the biofilm formation by Staphylococcus aureus, Escherichia coli and Pseudomonas aeruginosa isolated from bovine milk. Microbial Pathogenesis, 112, 5762. http://dx.doi.org/10.1016/j.micpath.2017.09.046. PMid:28943153.

Quast, C., Pruesse, E., Yilmaz, P., Gerken, J., Schweer, T., Yarza, P., Peplies, J., \& Glöckner, F. O. (2013). The SILVA ribosomal RNA gene database project: Improved data processing and web-based tools. Nucleic Acids Research, 41(D1), 590-596. http://dx.doi.org/10.1093/ nar/gks1219. PMid:23193283.

Quigley, L., O’Sullivan, O., Stanton, C., Beresford, T. P., Ross, R. P., Fitzgerald, G. F., \& Cotter, P. D. (2013). The complex microbiota of raw milk. FEMS Microbiology Reviews, 37(5), 664-698. http:// dx.doi.org/10.1111/1574-6976.12030. PMid:23808865.

Reichler, S. J., Trmčić, A., Martin, N. H., Boor, K. J., \& Wiedmann, M. (2018). Pseudomonas fluorescens group bacterial strains are responsible for repeat and sporadic postpasteurization contamination and reduced fluid milk shelf life. Journal of Dairy Science, 101(9), 77807800. http://dx.doi.org/10.3168/jds.2018-14438. PMid:29960782.

Russo, P., Fiocco, D., Albenzio, M., Spano, G., \& Capozzi, V. (2020). Microbial populations of fresh and cold stored donkey milk by highthroughput sequencing provide indication for a correct management of this high-value product. Applied Sciences, 10(7), 2314. http:// dx.doi.org/10.3390/app10072314.

Sader, H. S., Castanheira, M., Mendes, R. E., Flamm, R. K., Farrell, D. J., \& Jones, R. N. (2015). Ceftazidime-avibactam activity against 
multidrug-resistant Pseudomonas aeruginosa isolated in U.S. Medical Centers in 2012 and 2013. Antimicrobial Agents and Chemotherapy, 59(6), 3656-3659. http://dx.doi.org/10.1128/AAC.05024-14. PMid:25845861.

Salque, M., Bogucki, P. I., Pyzel, J., Sobkowiak-Tabaka, I., Grygiel, R., Szmyt, M., \& Evershed, R. P. (2013). Earliest evidence for cheese making in the sixth millennium bc in northern Europe. Nature, 493(7433), 522-525. http://dx.doi.org/10.1038/nature11698. PMid:23235824.

Samet-Bali, O., Felfoul, I., Lajnaf, R., Attia, H., \& Ayadi, M. A. (2013). Study of proteolytic and lipolytic activities of Pseudomonas spp. isolated from pasteurized milk in Tunisia. The Journal of Agricultural Science, 5(7), 46-50. http://dx.doi.org/10.5539/jas.v5n7p46.

Savaiano, D. A. (2014). Lactose digestion from yogurt: mechanism and relevance. The American Journal of Clinical Nutrition, 99(5, Suppl.), 1251S-1255S. http://dx.doi.org/10.3945/ajcn.113.073023. PMid:24695892.

Savelev, S. U., Perry, J. D., Bourke, S. J., Jary, H., Taylor, R., Fisher, A. J., Corris, P. A., Petrie, M., \& Soyza, A. (2011). Volatile biomarkers of Pseudomonas aeruginosa in cystic fibrosis and noncystic fibrosis bronchiectasis. Letters in Applied Microbiology, 52(6), 610-613. http:// dx.doi.org/10.1111/j.1472-765X.2011.03049.x. PMid:21438899.

Saxer, S., Schwenninger, S. M., \& Lacroix, C. (2013). Characterization of the microflora of industrial Mexican cheeses produced without added chemical preservatives. Lebensmittel-Wissenschaft + Technologie, 53(1), 314-320. http://dx.doi.org/10.1016/j.lwt.2013.01.016.

Scatamburlo, T. M., Yamazi, A. K., Cavicchioli, V. Q., Pieri, F. A., \& Nero, L. A. (2015). Spoilage potential of Pseudomonas species isolated from goat milk. Journal of Dairy Science, 98(2), 759-764. http:// dx.doi.org/10.3168/jds.2014-8747. PMid:25497792.

Serafini, F., Turroni, F., Ruas-Madiedo, P., Lugli, G. A., Milani, C., Duranti, S., Zamboni, N., Bottacini, F., van Sinderen, D., Margolles, A., \& Ventura, M. (2014). Kefir fermented milk and kefiran promote growth of Bifidobacterium bifidum PRL2010 and modulate its gene expression. International Journal of Food Microbiology, 178, 50-59. http://dx.doi.org/10.1016/j.ijfoodmicro.2014.02.024. PMid:24667318.

Singh, P. K., \& Shah, N. P. (2017). Other fermented dairy products: Kefir and koumiss. In N. P. Shah (Ed.), Yogurt in health and disease prevention (pp. 87-106). San Diego: Academic Press. http://dx.doi. org/10.1016/B978-0-12-805134-4.00005-5

Souza, I. T., Moreira, F. S., Ferreira, J. S., Cardoso, V. L., \& Batista, F. R. X. (2019). Technological advances in hydrogen production by Enterobacter bacteria upon substrate, luminosity and anaerobic conditions. International Journal of Hydrogen Energy, 44(31), 1619016198. http://dx.doi.org/10.1016/j.ijhydene.2019.05.036.

Uchida, K., Akashi, K., Motoshima, H., Urashima, T., Arai, I., \& Saito, T. (2009). Microbiota analysis of Caspian Sea yogurt, a ropy fermented milk circulated in Japan. Animal Science Journal, 80(2), 187-192. http://dx.doi.org/10.1111/j.1740-0929.2008.00607.x. PMid:20163589.

Ursell, L. K., Metcalf, J. L., Parfrey, L. W., \& Knight, R. (2012). Defining the human microbiome. Nutrition Reviews, 70(Suppl. 1), S38-S44. http://dx.doi.org/10.1111/j.1753-4887.2012.00493.x. PMid:22861806.

Vidal, A. M. C., Saran, A., No. Vaz, A. C. N., Capodifóglio, E., Gonçalves, A. C. S., Rossi, G. A. M., Figueiredo, A. S., \& Ruiz, V. L. A. (2017). Pseudomonas spp.: contamination sources in bulk tanks of dairy farms. Pesquisa Veterinária Brasileira, 37(9), 941-948. http://dx.doi. org/10.1590/s0100-736x2017000900008.

Walsh, A. M., Crispie, F., Kilcawley, K., O’Sullivan, O., O’ Sullivan, M. G., Claesson, M. J., \& Cotter, P. D. (2016). Microbial succession and flavor production in the fermented dairy beverage kefir. Applied and Environmental Science, 1(5), e00052-e16. http://dx.doi.org/10.1128/ mSystems.00052-16. PMid:27822552.

Wang, Y.-Y., Li, H.-R., Jia, S.-F., Wu, Z.-J., \& Guo, B.-H. (2006). Analysis of bacterial diversity of kefir grains by denaturing gradient gel electrophoresis and 16S rDNA sequencing. Acta Microbiologica Sinica, 46(2), 310-313. PMid:16736598.

Wanikawa, A., Shoji, H., Hosoi, K., \& Nakagawa, K. I. (2002). Stereospecificity of 10-hydroxystearic acid and formation of 10-ketostearic acid by lactic acid bacteria. Journal of the American Society of Brewing Chemists, 60(1), 14-20. http://dx.doi.org/10.1094/ASBCJ-60-0014.

Wen, C., Wu, L., Qin, Y., Van Nostrand, J. D., Ning, D., Sun, B., Xue, K., Liu, F., Deng, Y., Liang, Y., \& Zhou, J. (2017). Evaluation of the reproducibility of amplicon sequencing with Illumina MiSeq platform. PLoS One, 12(4), e0176716. http://dx.doi.org/10.1371/ journal.pone.0176716. PMid:28453559.

Xu, Z., Xie, J., Soteyome, T., Peters, B. M., Shirtliff, M. E., Liu, J., \& Harro, J. M. (2019). Polymicrobial interaction and biofilms between Staphylococcus aureus and Pseudomonas aeruginosa: an underestimated concern in food safety. Current Opinion in Food Science, 26, 57-64. http://dx.doi.org/10.1016/j.cofs.2019.03.006.

Yasmin, N., Hameed, S., Javed, R., Ahmed, S., \& Imran, M. (2017). Inactivation of foodborne pathogens on food packaging and in cow milk by exposure to a Nd:YAG laser. Canadian Journal of Physics, 95(7), 662-669. http://dx.doi.org/10.1139/cjp-2016-0676.

Zechman, M., \& Labows, J. N., Jr. (1985). Volatiles of Pseudomonas aeruginosa and related species by automated headspace concentration - gas chromatography. Canadian Journal of Microbiology, 31(3), 232237. http://dx.doi.org/10.1139/m85-045. PMid:3924382.

Ziadi, M., Wathelet, J. P., Marlier, M., Hamdi, M., \& Thonart, P. (2008). Analysis of volatile compounds produced by 2 strains of Lactococcus lactis isolated from leben (Tunisian fermented milk) using solid-phase microextraction-gas chromatography. Journal of Food Science, 73(6), S247-S252. http://dx.doi.org/10.1111/j.17503841.2008.00846.x. PMid:19241567. 


\section{Supplementary Material}

Supplementary material accompanies this paper.

Fig. S1. Alpha rarefaction curves of observed bacterial OTUs (operational taxonomic units) from the temporal samples of Caspian Sea-style fermented milk (A). raw milk. and viability tests (B).

Table S1. Relative abundance (\%) of low abundance bacteria at family and genus level during Caspian sea-style fermentation process. $\mathrm{ND}=$ not determined; $\mathrm{VT}=$ viability test.

This material is available as part of the online article from http://www.scielo.br/CTA 